\title{
Endoscopic extraction of Fasciola hepatica: a case report
}

\section{Fasciola hepatica'nın endoskopik olarak çıkarılması: bir vaka}

\author{
Nevzat ÜNAL ${ }^{1}, \quad$ Yeliz TANRIVERDi-ÇAYCl ${ }^{2}$, Özgür ECEMiş3 ${ }^{3}, \quad$ Ahmet BEKTAŞ ${ }^{4}, \quad$ Murat HÖKELEK ${ }^{5}$
}

\begin{abstract}
Fasciola hepatica infection is a zoonosis mostly encountered in the sheep-raising countries. The early phase $F$. hepatica infection is characterised by fever, abdominal pain and eosinophilia. The biliary obstruction and icterus are rarely caused by F. hepatica. Our case was a 22-years old female, from Giresun, a north coast city of Turkey, who applied because of icterus and abdominal pain. To analyse the problem abdominal US and laboratory tests was performed which showed dilation in the proximal of choledochal and tubuler echogenites and elevated hepatic enzymes. Endoscopic retrograde cholangiopancreatography showed minimal dilatation of intrahepatic bile ducts and heterogenous filling defect in the hilus. Biliary sphincterotomy had been applied and $F$. hepatica had been removed by balloon catheter. This case report showed that endoscopic retrograde cholangiopancreatography (ERCP) has an important role in the diagnosis and the treatment of biliary fascioliasis.
\end{abstract}

Key Words: Fasciola hepatica, biliary obstruction, ERCP

\section{ÖZET}

Fasciola hepatica koyun yetiștiriciliği yapılan ülkelerde sıklıkla görülen bir zoonozdur. $F$. hepatica enfeksiyonu erken dönemde ateș, karın ağrısı ve eozinofili ile karakterizedir. $F$. hepatica nadiren bilier tıkanıklık ve iktere neden olur. Vakamız, Türkiye'nin kuzey kıyı șeridinde bir șehir olan Giresun'dan karın ağrısı ve ikter nedeniyle gelen 22 yașında bayan hastadır. Nedeni araștırmak için yapilan batın ultrasonu ve laboratuvar testlerinde; proksimal koledokta genişleme ve tubuler ekojenite ile karaciğer enzimlerinde yükselme görülmüștür. Endoskopik retrograd kolanjiopankreatografi'de intrahepatik safra kanallarında minimal genișleme ve hilusta heterojenöz dolma defekti görülmüștür. Biliar sfinkterotomi uygulanmış ve $F$. hepatica balon kateter ile çıkarılmıștır. Bu vakada endoskopik retrograd kolanjiopankreatografi (ERCP)'nin fasiyoliyaz tanı ve tedavisinde önemli bir role sahip olduğu görülmüștür.

Anahtar Kelimeler: Fasciola hepatica, safra tıkanıklığı, ERCP

\footnotetext{
${ }^{1}$ Adana Numune Education and Research Hospital, Laboratory of Microbiology, ADANA

${ }^{2}$ Ondokuz Mayis University, Medical Faculty, Department of Medical Microbiology, SAMSUN

${ }^{3}$ Medical Park Hospital, Gastroenterology, SAMSUN

${ }^{4}$ Ondokuz Mayis University, Medical Faculty, Department of Gastroenterology, SAMSUN

${ }^{5}$ Istanbul University, Cerrahpasa Medical Faculty, Department of Medical Microbiology, ISTANBUL
}

\section{İletişim/Corresponding Author : Nevzat ÜNAL Adana Numune Education and Research Hospital, Laboratory of Microbiology, ADANA}

Tel : +905324426142_E-posta/E-mail : drnevzatunal@hotmail.com 


\section{INTRODUCTION}

Fascioliasis is caused by flukes of the genus Fasciola (1). Fasciola hepatica infection is a zoonosis mostly encountered in the sheep-raising countries (2). Adult Fasciola hepatica lives in small passages of the liver of many kinds of mammals, particulary ruminants. Humans are occasionally infected. But it has been estimated that it has affected 2.4 million person across the world (1).

The adult fluke is large, flat, brownish and leaf shaped. The ovum of $F$. hepatica passes to the faeces through the intestine and so contaminates water and completes its development in water. In the water, miracidia hatch and reach to the snail which is the intermediate host of the worm. In the intermediate host, cercariae develop and encyst into metacercariae on aquatic grasses and plants. When eating infected material, infective metacercariae excyst in the duodenum and larvae emerge. The larvae penetrate the wall of the small intestine into the peritoneal cavity and then penetrate the liver capsule and pass through the liver tissue into the biliary tract (2).

The clinical presentation of $F$. hepatica infection has two different phases. The early phase is characterized by fever, abdominal pain and eosinophilia (2). F. hepatica infection may be asymptomatic. Heavy infections can lead to cholestasis and result in hepatic atrophy and periportal cirrhosis (1). There are some cases in which hemobilia and pancreatitis were reported (3).

Adult parasites can survive up to 10 years. In humans, approximately 12 to 16 weeks are needed from infection to oviposition. In this period, it is possible to diagnose the fascioliasis serologically. Finding of the characteristic ova in the stool is used in the diagnosis of fascioliasis. Also radiological imaging methods like ultrasound (US), endoscopic retrograde cholangiopancreatography (ERCP) and magnetic resonance imaging (MRI) can also be used in the diagnosis $(1,2)$.

The biliary obstruction and icterus are rarely caused by $F$. hepatica. We present a patient with biliary obstruction who was diagnosed and treated by ERCP.

\section{CASE}

Our case was a 22-years old female, from Giresun; a north coast city of Turkey, who came because of icterus and abdominal pain. She had no symptoms until one week admission to the state hospital in Giresun. She had episodic right upper quadrant pain especially after meal but unrelated to the position or respiration. Her pain was accompanied by nausea. She had no fever. In order to analysis the problem abdominal US and laboratory tests were performed. US showed dilatation of the external bile ducts proximal to choledoc and tubuler echogenites in the common bile duct. Hepatic enzymes were elevated. Based on the US and laboratory tests, ERCP was suggested to the patient and she was referred to our hospital which is a tertiary care medical center.

In our hospital, her physical examination was normal but she had right upper quadrant tenderness. Laboratory test results were as follows; white blood cell $6200 / \mu \mathrm{L}$ (34.7\% lymphocytes, $41 \%$ neutrophils, $10.4 \%$ monocytes and $12.7 \%$ eosinophils), alanine aminotransferase 354.23 $\mathrm{U} / \mathrm{L}$; aspartate aminotransferase $264.2 \mathrm{U} / \mathrm{L}$; gama glutamyl transferase $100.5 \mathrm{U} / \mathrm{L}$; amylase 1677.19 $\mathrm{U} / \mathrm{L}$; lipase $3000 \mathrm{U} / \mathrm{L}$; pancreatic amylase 1567.62 $\mathrm{U} / \mathrm{L}$; total bilirubin $1.9 \mathrm{mg} / \mathrm{dl}$; direct bilirubin $0.68 \mathrm{mg} / \mathrm{dl}$. The urine color was orange and positive for urobilinogen. ERCP showed dilatation of common bile duct and heterogenous filling defect in it. Biliary sphincterotomy has been performed and $F$. hepatica was removed by balloon catheter (Figures 1, 2). 


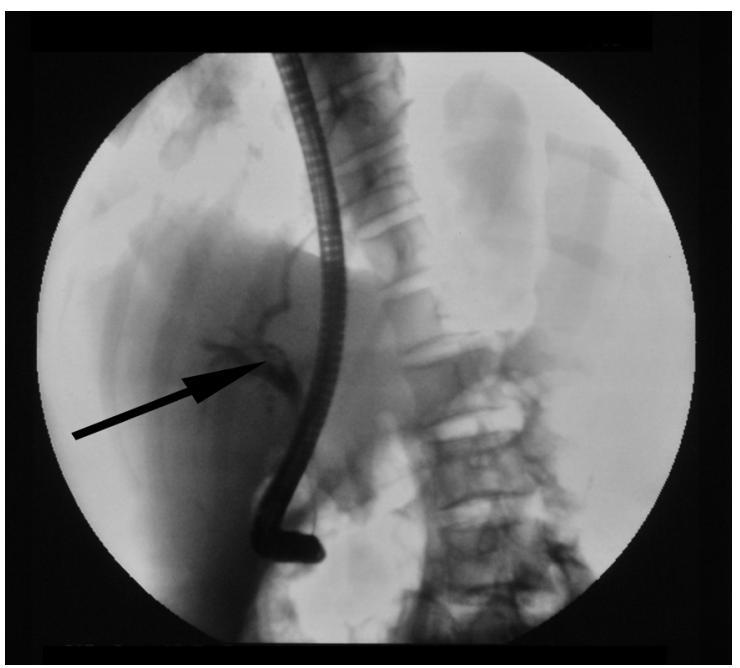

Figure 1. Filling defect within the common bile duct during endoscopic retrograde cholangiography (ERCP)

\section{DISCUSSION}

Human fascioliasis is a worldwide illness (4). Acute illness occurs due to the tissue damage (1). Infection in human usually causes by eating watercress grown in sheep-raising areas. The symptoms of the disease change by the phase of infection. The acute or hepatic stage symptoms are pain, pruritis, weight loss and eosinophilia. Generally, blood transaminase levels are normal or minimally elevated. The biliary phase is asymptomatic and extrahepatic obstruction and cholestasis are rarely reported (5). There were less than 50 cases reported across the world which have cholestasis and biliary obstruction. Interesting points of our case are, she is young, healthy and living in a coast city.

Tuna reported a case diagnosed as fascioliasis by ERCP. The patient was 44 years old and had abdominal pain, nausea and vomiting (6). Another case, reported by Deveci et al. was a nine-years old boy who had nausea, epigastric pain, decreased appetite and eating complaints. They were diagnosed the fascioliasis by serological tests and radiological examinations (7). Clinical spectrum of fascioliasis is wide and has similar symptoms and signs as other helminthic

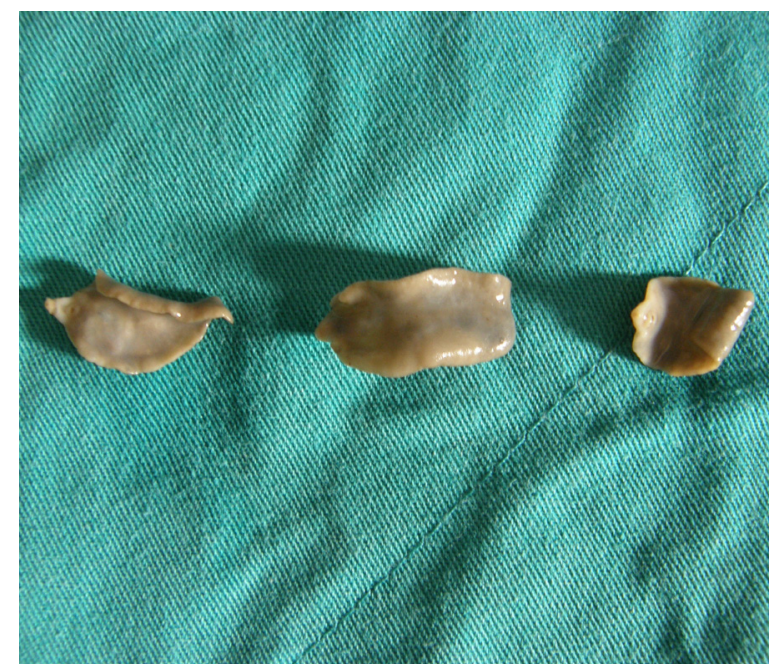

Figure 2. A macroscopic image of extracted adult Fasciola hepatica parasites

infections. Sera samples of 226 cases, suspected of cystic echinococcosis had been evaluated for cystic echinococcosis and fascioliasis. Among them five $(2 \%)$ were found seropositive for fascioliasis (8).

Identifying $F$. hepatica eggs in stool samples was the most commonly used main diagnostic method (2). Stool can be examined for eggs during the biliary stage of the infection. Eggs are nonembryonated and ovoid with a small operculum. However, this method has some disadvantages because eggs do not appear during the migration stage. The immunologic tests and radiological techniques are other methods used in the diagnosis of fascioliasis. An enzyme-linked immunosorbent assay (ELISA) has a sensitivity of $100 \%$ and specificity of $97,8 \%$. US and especially ERCP have important role in the diagnosis and treatment of F. hepatica infection as in our case (5). There were some previous reports in three patients that ERCP and sphincterotomy were successful for extracting the parasites (9). In the diagnosis of $F$. hepatica MRI shows characteristic parenchymal lesions and it is better than computer tomography (CT) in the early stage of fascioliasis (4). 
Treatment of $F$. hepatica infections have some difficulties. Unlike other flukes, praziquentel has no effect on $F$. hepatica. Antiparasitic agents used in the past like parenteral dehydroemetine and oral bithional are not effective, either. In our case, triclabendazole was suggested for treatment. It is highly effective against the mature and immature forms of worms (10).
In conclusion, biliary obstruction is a rare complication of fascioliasis. Physicians should be aware of this disease when a patient has abdominal pain, elevated or normal hepatic enzymes, icterus and eosinophilia. ERCP has an important role in the diagnosis and the treatment of the disease and can be used safely.

\section{REFERENCES}

1. Jones MK, Mcmanus DP. Trematodes. In: Murray $\mathrm{P}$, Baron EJ, Jorgensen JH, Landry ML, Pfaller MA, eds. Manual of Clinical Microbiology. 9th ed, Washigton, DC. ASM Press, 2007: 2175-87.

2. Adel AFM. Trematodes and Other Flukes. In: Mandell GL,Bennett JE, Dolin R, eds. Principles and Practice of Infectious D, 7th ed, Philadelphia, 2009: 2954-6.

3. Bahcecioglu IH, Ataseven H, Aygen E, Coskun S, Kuzu N, Ilhan F. Fasciola hepatica case with hemobilia. Acta Medica, 2007; 50: 155-156.

4. Taheri MS, Aminzade Z, Shokohi SH, Birong SH, Aghazade K. Hepatobiliary Fascioliasis: Clinical and Radiological Features. Iran J Parasitol, 2007; 2: $48-55$

5. Moghadami M, Moradni M. Fasciola hepatica: A cause of obstructive jaundice in an elderly man from Iran. Saudi J Gastroenterol, 2008; 14: 208210. doi: $10.4103 / 1319-3767.43279$
6. Tuna Y. Endoscopic management of biliary fasciolosis. Cumhuriyet Med J, 2011; 33: 469- 72. DOI: http://dx.doi.org/10.7197/cmj.v33i4

7. Deveci U, Öztürk T, Üstün C. Radyolojik Olarak Tanı konulan Pediatrik Fasciola hepatica Olgusu. Turkiye Parazitol Derg, 2011; 35: 117-9. DOI: 10.5152/tpd.2011.29

8. Sakru N, Korkmaz M, Demirci, Kuman A, Ok ÜZ. Fasciola hepatica infection in Echinococcosis suspected cases. Turkiye Parazitol Derg, 2011; 35: 77-80. doi:10.5152/tpd.2011.20

9. Ozer B, Serin E, Gümürdülü Y, Gür G, Yılmaz U, Boyacioglu S. Endoscopic extraction of living Fasciola hepatica: Case report and literature review. Turkish J Gastroenterol, 2003; 14: 74-7.

10. Echenique-elizonde $M$, Amandarain J, Lironde de Robles C. Fascioliasis: An exceptional cause of acute pancreatitis. J Pancreas, 2005; 6: 36-39. 